\title{
Catalytic Activities of $\mathrm{Fe}^{3+}$ and $\mathrm{Zn}^{2+}$-Natural Zeolite on the Direct Cyclisation-Acetylation of $(R)-(+)-C i t r o n e l l a l$
}

\author{
Edy Cahyono *1, M. Muchalal ${ }^{2}$, T. Triyono ${ }^{2}$, Harno Dwi Pranowo ${ }^{2}$ \\ ${ }^{1}$ Department of Chemistry, Universitas Negeri Semarang, Sekaran, Gunungpati, \\ Semarang 50229, Indonesia \\ ${ }^{2}$ Department of Chemistry, Gadjah Mada University, Sekip Utara, Yogyakarta 55281, Indonesia
}

Received: 18th December 2013; Revised: 9th April 2014; Accepted: 17th April 2014

\section{Abstract}

An investigation on characterisation and catalytic ativities of modified natural zeolite on cyclisationacetylation reaction of $(\mathrm{R})-(+)$-citronellal was performed. The experimental works involved the isolation of (R)-(+)-citronellal from Javanese citronella (Cymbopogon winterianus) oil by vacuum fractional distillation, the determination of its enantiomers, and the preparation and characterisation of different catalysts i.e. $\mathrm{H}$-natural zeolite $(\mathrm{H}-\mathrm{Za}), \mathrm{Fe}^{3+}$-natural zeolite $\left(\mathrm{Fe}^{3+}-\mathrm{Za}\right)$, and $\mathrm{Zn}^{2+}$-natural zeolite $\left(\mathrm{Zn}^{2+}-\mathrm{Za}\right)$, followed by the examination of their activity and selectivity on cyclisation-acetylation reaction of (R)(+)-citronellal. The isolated citronellal contained 88.21 ee.\% of (R)-(+)-citronellal. The crystallinity and the morphology of the modified zeolites showed that the natural zeolite from Malang Indonesia has the main component of mordenite-type zeolite. The main products of cyclisation-acetylation of (R)-(+)citronellal were isopulegyl acetate (IPA) and neo-isopulegyl acetate (NIPA). Fe ${ }^{3+}-\mathrm{Za}$ catalyst showed the highest activity towards IPA and NIPA production but its stereoselectivity was slightly lower than that of $\mathrm{Zn}^{2+}$-Za catalyst. It is shown that Lewis acidity plays the role in the formation of acetyl ionic from acetic anhydride. (C) 2014 BCREC UNDIP. All rights reserved

Keywords: (R)-(+)-citronellal; isopulegyl acetate; $\mathrm{Fe}^{3+-}$ and $\mathrm{Zn}^{2+}$-natural zeolite

How to Cite: Cahyono, E., Muchalal, M., Triyono, T., Pranowo, H.D. (2014). Catalytic Activities of $\mathrm{Fe}^{3+}$ - and $\mathrm{Zn}^{2+}$-Natural Zeolite on the Direct Cyclisation-Acetylation of (R)-(+)-Citronellal. Bulletin of Chemical Reaction Engineering \& Catalysis, 9 (2): 128-135. (doi:10.9767/bcrec.9.2.5936.128-135)

Permalink/DOI: http://dx.doi.org/10.9767/bcrec.9.2.5936.128-135

\section{Introduction}

Citronellal is one of monoterpenes that presents in some essential oils [1] and can also be obtained by hydrogenation of citral [2]. Transformation of citronellal was studied in the synthesis of fine chemicals such as menthol, isopulegol, and isopulegyl acetate. Isopulegyl acetate (IPA) is a fine chemical widely employed in flavor and perfume industries for the production

\footnotetext{
* Corresponding Author.

E-mail: edkim@mail.unnes.ac.id or edkim_unnes@yahoo.co.id (E. Cahyono)
}

of fragrances and for manufacturing important ingredients of various foods and cleaner products. The synthesis of IPA is generally carried out through the selective one-step or two-steps cyclisation and acetylation of citronellal to unsaturated cyclic alcohol acetate over acid catalysts. Acid-catalysed carboxylic acid esterification and Friedel-Crafts acylation reactions are important synthetic reactions for the preparation of value-added key organic intermediates. Preparation of alkyl esters is of particular importance in the manufacture of intermediates for the fragrances and pharmaceutical indus- 
tries [3].

In normal practice, strong mineral acids such as $\mathrm{H}_{2} \mathrm{SO}_{4}, \mathrm{HF}$, or supported-Lewis acid catalysts such as anhydrous $\mathrm{AlCl}_{3} / \mathrm{SiO}_{2}$ and $\mathrm{BF}_{3} / \mathrm{SiO}_{2}$, are used for such reactions. However, the use of corrosive mineral acids or Lewis acid catalysts is associated with a number of environmental concerns [4-5]. A major drawback of such catalytic systems is that they cannot be regenerated, and more than the stoichiometric amount of catalyst for Friedel-Crafts acylation is needed. To avoid major environmental hazards and to satisfy the global environmental regulations which have been growing stringently, it is imperative to develop a catalytic process with minimal waste production.

Characterisation and catalytic activity examination of modified synthetic zeolites and natural zeolites from several countries were reported on some organic reactions such as in Knoevenagel condensation reaction [6], synthesis of fragrances [7], and cyclisation of citronellal into isopulegol $[8,9]$. Cyclysation-acetylation of citronellal with $\mathrm{FeCl}_{3}$ Catalyzed showed that in high temperature selectivity to produce IPA was low, and the major product was $p$-cymene as the side product [10].

In this study, the activity and selectivity of the modified zeolite catalysts in transformation reaction of citronellal to isopulegyl acetate (IPA) have been investigated. This transformation involves one-step cyclisation-acetylation reaction. The modification towards the Indonesian natural zeolite was conducted by acid treatment, calcination, and ion exchange to increase the Lewis acidity of catalysts.

One of the most interesting aspects in the synthesis of IPA is the stereo-selectivity of products. Therefore, in order to be commercially attractive, synthesis of IPA must be highly stereo-selective. The primary objective of this research was to compare the activity of different Lewis acids supported on modified natural zeolite as the catalysts in the direct cyclisation-acetylation of $(R)-(+)$-citronellal with acetic anhydride in a systematic way.

\section{Materials and Methods}

\subsection{Materials}

Javanese Citronella oil (Cymbopogon winterianus) was obtained from Yogyakarta, Indonesia and the natural zeolite was obtained from Malang, East Java, Indonesia. Zinc chloride, ferric chloride, acetic anhydride, $n$-hexane, and sodium sulphate anhydrous were in analytical grades and purchased from Merck. (R)-(+)- citronellal used as a standard was obtained from Sigma Aldrich.

\subsection{Methods}

A set of vacuum fractional distillation was used for isolation of citronellal from citronella oil. A set of reflux glassware equipped with a cooler and filled with nitrogen was used as a reactor. Composition of citronella oil, distillate, and crude products was determined by an enantioselective gas chromatograph, GC (Hewlett Packard 5890 Series II) equipped with a 30 $\mathrm{m} \times 0.25 \mathrm{~mm}$ i.d. $\times 0.25 \mathrm{\mu m}$ film thickness of $\mathrm{Su}$ pelco B-DEX 225 capillary column and an FID detector. Structure elucidation of citronellal and its products was conducted by using gas chromatograph-mass spectrometer, GC-MS Shimadzu QP 5000. Characteristics of catalysts were investigated by means of X-ray diffractometer Shimadzu XRD 600), surface areameter NOVA 1000, atomic adsorption spectrometer AA 280 FS Shimadzu, transmission electron microscope (TEM, JEOL JEM3010 HRTEM $300 \mathrm{kV}$ ), scanning electron microscope (SEM, JEOL JED-2300 $15 \mathrm{kV}$ ), and temperatureprogrammed desorption of ammonia $\left(\mathrm{NH}_{3}\right.$ TPD) instrument.

\subsubsection{Isolation of Citronellal}

Citronellal was isolated from citronella oil by vacuum fractional distillation. An enantioselective capillary GC on a Supelco B-DEX 225 column has been used for analysing the enantiomer ratio of citronellal. The determination of the enantiomer ratio of citronellal was based on the ratio of peak area of each enantiomer shown in the chromatogram.

Structure analysis of citronellal was conducted by identifying the peaks in the total ion chromatogram based on NIST and Wiley library, as well as the spiking method i.e. injection of the mixture of isolated citronellal and $(R)$-(+)-citronellal standard.

\subsubsection{Catalyst Preparation and Characterisation}

H-natural zeolite ( $\mathrm{H}-\mathrm{Za})$ catalyst was prepared through acid activation towards natural zeolite from Malang, Indonesia using 1\% of $\mathrm{HF}$ and $6 \mathrm{M}$ of $\mathrm{HCl}$ solution followed by ionexchange with $3 \mathrm{M}$ of $\mathrm{NH}_{4} \mathrm{Cl}$ solution. The obtained solid then subsequently underwent a calcination process at $450{ }^{\circ} \mathrm{C}$ for an hour under nitrogen atmosphere. H-Za was transformed to $\mathrm{Zn}^{2+}-\mathrm{Za}$ and $\mathrm{Fe}^{3+}-\mathrm{Za}$ by ion-exchange with 0.1 $\mathrm{M} \mathrm{ZnCl}_{2}$ and $0.1 \mathrm{M} \mathrm{FeCl}_{3}$ solution, respectively. 
The amount of cation adsorbed on the catalyst surface and the Si/Al ratio of both natural zeolite and $\mathrm{H}-\mathrm{Za}$ are of importance. Analysis of adsorbed $\mathrm{Fe}^{3+}$ and $\mathrm{Zn}^{2+}$ on catalysts and $\mathrm{Si} / \mathrm{Al}$ ratio of natural zeolite and $\mathrm{H}-\mathrm{Za}$ was carried out using AAS by measuring the total corresponding metals. The difference of the amount of active metal ion $\left(\mathrm{Fe}^{3+}\right.$ and $\left.\mathrm{Zn}^{2+}\right)$ in the solution before and after modification was the amount of active metal ion loaded on the zeolite surface. The determination of Si content on the catalyst surface was performed by gravimetric method.

The study of the crystallinity of the natural zeolite in the $\mathrm{Zn}^{2+}-\mathrm{Za}$ and $\mathrm{Fe}^{3+}-\mathrm{Za}$ catalysts was carried out by using X-ray diffractometer Shimadzu XRD 600 at $2 \theta$ of $0-50^{\circ}$. The micrograph with magnification of 50,000x were obtained by means SEM JEOL JED-2300 $15 \mathrm{kV}$ and TEM JEOL JEM3010 HRTEM $300 \mathrm{kV}$ to study the outer and inner morphology of the catalysts. Based on the crystallinity and morphology, the main component of Indonesian natural zeolite can be determined. The surface and porous properties of the catalysts were studied using nitrogen adsorption experiments using NOVA 1000 apparatus at $77.35 \mathrm{~K}$. The specific surface area $\mathrm{S}_{\text {BET }}$ was calculated from BET adsorption isotherm in a range of relative pressure of $0.100 / 0.100 \mathrm{p} / \mathrm{p}_{0}$. The value of total pore volume $\mathrm{V}_{\mathrm{a}}$ was estimated from the maximum adsorption at relative pressure of $1.00 \mathrm{p} / \mathrm{p}_{0}$. The t-plot method has been used to characterize the porous properties of $\mathrm{H}-\mathrm{Za}, \mathrm{Fe}^{3+}-\mathrm{Za}$, and $\mathrm{Zn}^{2+}-\mathrm{Za}$.

TPD spectra were recorded using a conventional flow system equipped with a thermal conductivity detector [11-12]. The details of acidity measurement using $\mathrm{NH}_{3}$-TPD can be found elsewhere [13].

\subsubsection{Synthesis of IPA stereisomers}

Cyclisation-acetylation reaction was carried out by heating $7.1 \mathrm{ml}$ of citronellal $(60 \mathrm{mmol})$, $11.2 \mathrm{ml}$ of acetic anhydride (120 mmol), and $1 \mathrm{~g}$ of catalyst in glass-made batch reactor equipped with a magnetic stirrer and thermometer. The reaction was carried out at temperature range of $0-80{ }^{\circ} \mathrm{C}$ under nitrogen atmosphere with a vigorous stirring. As the reaction proceeded, $1 \mathrm{ml}$ of samples was taken from the system at $10,20,30,60,120$, and 180 minutes. To obtain the organic phase, the samples were added with $2 \mathrm{ml}$ of $n$-hexane and diluted with aquadest until the volume reached $10 \mathrm{ml}$. To separate the organic phase from the solid and aqueous phase, the mixture was centrifuged. The organic phase then was analysed using GC and GC-MS.

\section{Results and Discussion}

\subsection{Isolation of (R)-(+)-Citronellal}

The composition of citronella oil depends on the species and where the plant is grown. Based on the concentration of citronellal, the citronella oil from Yogyakarta, Indonesia was selected. The total ion chromatogram and mass spectra of the citronella oil showed that the main compounds in citronella oil were citronellal (about 47\%), citronellol, and geraniol. Vacuum Fractional distillation of $250 \mathrm{ml}$ of the citronella oil resulted in two fractions. The redistillation of the second fraction at and 110$120{ }^{\circ} \mathrm{C}$ under $5 \mathrm{~cm} \mathrm{Hg}$ pressure obtained $68 \mathrm{ml}$ of distillate with higher citronellal content $(97.30 \%)$. GC analysis showed that the isolated citronellal contained 88.21 ee.\% of $(R)-(+)$ citronellal (peak area based). Mass spectra showed that citronellal shows the fragmentation pattern at $\mathrm{m} / \mathrm{z}=154,139,121,95,83,69$, 55 , and 41 (base peak). It agrees with the structure elucidation and enantiomer ratio analysis of citronellal reported earlier [14].

\subsection{Catalysts Characterisation}

\subsubsection{Adsorbed cation and $\mathrm{Si} / \mathrm{Al}$ ratio}

The amount of $\mathrm{Fe}^{3+}$ on $\mathrm{Fe}^{3+}-\mathrm{Za}$ and $\mathrm{Zn}^{2+}$ on $\mathrm{Zn}^{2+}-\mathrm{Za}$ was 0.9467 and $0.6914 \mathrm{mg} / \mathrm{g}$ of catalyst, respectively. Lewis acidity of $\mathrm{Fe}^{3+}$ is higher than that of $\mathrm{Zn}^{2+}$. Lewis acidity has a role in cation adsorption at the active sites of the solid surface [15].

The ratios of $\mathrm{Si} / \mathrm{Al}$ of natural zeolite and $\mathrm{H}$ $\mathrm{Za}$ as the ratio of $\mathrm{Al}\left(\mathrm{Al}_{2} \mathrm{O}_{3}\right)$ to $\mathrm{Si}\left(\mathrm{SiO}_{2}\right)$ were 6.55 and 6.93 , repectively. It is in agreement with mordenite-type mineral which is obtained in Mexico. It has chemical composition of $72.12 \% \mathrm{SiO}_{2}$ and $11.96 \% \mathrm{Al}_{2} \mathrm{O}_{3}$ with $\mathrm{Si} / \mathrm{Al}$ ratio of 5.91 [15].

\subsubsection{Catalysts Acidity}

Modified natural zeolite catalysts have better acidity than natural zeolite has. Total acidity of the catalyst is assumed as the number of Brönsted and Lewis acid sites located on the surface of the catalyst. In this study, the acidity is defined as the amount of mmol adsorbed $\mathrm{NH}_{3}$ per gram of catalyst. Table 1 shows the acidity of modified natural zeolite.

The acidity of $\mathrm{Fe}^{3+}-\mathrm{Za}$ and $\mathrm{Zn}^{2+}-\mathrm{Za}$ is lower than that of H-Za. It is shown that the exchange of proton by $\mathrm{Fe}^{3+}$ and $\mathrm{Zn}^{2+}$ caused an increase in Lewis acid sites and a decrease in Brönsted acid sites. Figure 1 shows the $\mathrm{NH}_{3}$ desorption spectra of catalysts. Desorption of $\mathrm{NH}_{3}$ 
on the Brönsted acid sites surface might occur when the samples were heated up from 200 to $470{ }^{\circ} \mathrm{C}$ and desorption of $\mathrm{NH}_{3}$ from the Lewis acid sites occurred at 470 to $650{ }^{\circ} \mathrm{C}$ [17]. Based on the $\mathrm{NH}_{3}$ desorption spectra, Brønsted acidity of catalysts are stronger than Lewis acidity.

\subsubsection{Porosity}

Analysis of the porosity of natural zeolite, $\mathrm{H}-\mathrm{Za}, \mathrm{Fe}^{3+}-\mathrm{Za}$, and $\mathrm{Zn}^{2+}-\mathrm{Za}$ catalysts by means NOVA gas sorption analyzer was aimed to calculate the quantity of $\mathrm{N}_{2}$ as an adsorbate on the catalyst surface. BET equation was used to calculate the specific surface area, average pore radii, and total pore volume. The results of porosity measurement are presented in Table 2 .

The average pore radius of natural zeolite is larger than that of $\mathrm{H}-\mathrm{Za}$. Acid treatment and calcination natural zeolite into $\mathrm{H}$-Za reduced the average pore radii and increased the pore volume and surface area. Ion exchange caused an increase in average pore volume but reduced the surface area. This situation illustrates that the distribution of metal cations is not only inside the pores but it is also possible to be distributed in the outer pores. Such distribution will reduce the catalyst stereoselectivity as expected only product IPA stereoisomers. The diversity of mineral

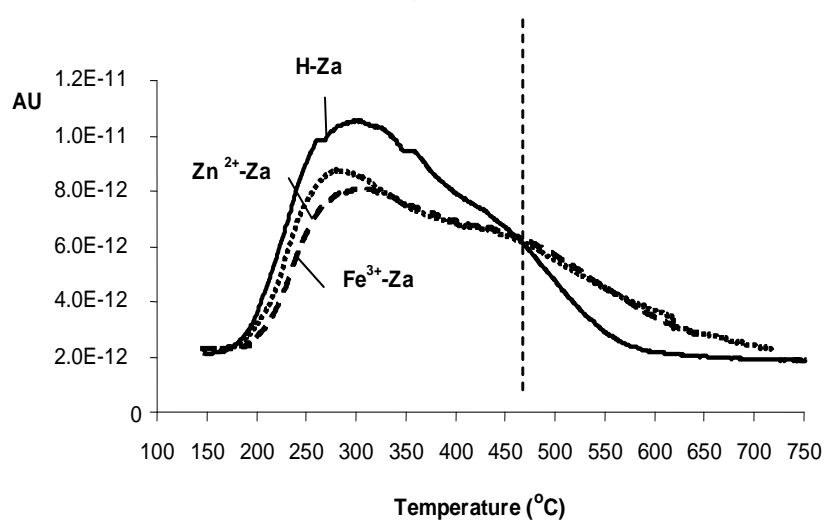

Figure 1. $\mathrm{NH}_{3}$ desorption spectra of $\mathrm{H}-\mathrm{Za}$, $\mathrm{Zn}^{2+}-\mathrm{Za}$, and $\mathrm{Fe}^{3+}-\mathrm{Za}$

Table 1. The acidity of $\mathrm{H}-\mathrm{Za}, \mathrm{Zn}^{2+} \mathrm{Za}$, and $\mathrm{Fe}^{3+-}$ Za by $\mathrm{NH}_{3}$-TPD method

\begin{tabular}{ccc}
\hline Sample & $\begin{array}{c}\text { Weight } \\
(\mathrm{g})\end{array}$ & $\begin{array}{c}\text { Acidity } \\
\left(\mathrm{mmol} \mathrm{NH}_{3} / \mathrm{g} \text { catalyst }\right)\end{array}$ \\
\hline $\mathrm{H}-\mathrm{Za}$ & 0.3055 & 1.0336 \\
$\mathrm{Zn} 2+-\mathrm{Za}$ & 0.2785 & 1.0182 \\
$\mathrm{Fe} 3+-\mathrm{Za}$ & 0.3537 & 0.6445 \\
\hline
\end{tabular}

constituent of natural zeolite catalyst causes the inhomogenity of surface and pores [18].

\subsubsection{X-Ray Diffraction}

Diffraction patterns of natural zeolite, H-Za, $\mathrm{Fe}^{3+-} \mathrm{Za}$, and $\mathrm{Zn}^{2+}-\mathrm{Za}$ are presented in Figure 2 . The diffractogram of $\mathrm{H}-\mathrm{Za}, \mathrm{Fe}^{3+}-\mathrm{Za}$, and $\mathrm{Zn}^{2+}$ $\mathrm{Za}$ has the same appearance. Based on the results of $\mathrm{XRD}$ analysis, it is concluded that natural zeolite from Malang used in this study is mainly composed of Mordenite.

\subsubsection{Morphology of catalysts}

Figure 3 shows SEM micrographs of $\mathrm{H}-\mathrm{Za}$, $\mathrm{Zn}^{2+}-\mathrm{Za}$, and $\mathrm{Fe}^{3+}-\mathrm{Za}$. These images prove the morphological features of mordenite. Micrographs of modified natural zeolite catalysts in Figure 3 have the same pattern as the micrograph of synthetic mordenite with a mole ratio of $\mathrm{SiO}_{2}: \mathrm{Al}_{2} \mathrm{O}_{3}: \mathrm{Na}_{2} \mathrm{O}=50.00: 24.20$ : 25.80 [19].

TEM analysis was carried out to study the local structure, morphology, and the distribution of active metal ion on the catalyst surface. Figure 4 (a) is the crystal morphology of $\mathrm{Zn}^{2+}$. Za. This morphology is similar to mordenite micrograph [20]. Distribution of metal on the surface is shown by dark spots in Figure 4 (b). The distance between spots varied from $4 \mathrm{~nm}$ to $12 \mathrm{~nm}(40-120 \AA)$. Since the average pore radii of $\mathrm{Zn}^{2+} \mathrm{Za}$ from $\mathrm{BET}$ analysis is $46.20 \AA$ (Table 4), it can be stated that metal cations are distributed on the surface of the pores and the outer pore surface.

\subsubsection{Activity and Selectivity Examina- tions of Catalysts}

The best catalyst for cyclisation reaction of citronellal-acetylation is the catalyst that has

Table 2. Pore radii, pore total volume, and surface area of natural zeolite, $\mathrm{H}-\mathrm{Za}, \mathrm{Fe}^{3+}-\mathrm{Za}$, and $\mathrm{Zn}^{2+}-\mathrm{Za}$

\begin{tabular}{cccc}
\hline & \multicolumn{3}{c}{ Porosity } \\
\cline { 2 - 4 } Sample & $\begin{array}{c}\text { Pore } \\
\text { radii }(\AA)\end{array}$ & $\begin{array}{c}\text { Total pore } \\
\text { volume } \\
(\mathrm{cc} / \mathrm{g})\end{array}$ & $\begin{array}{c}\text { Surface } \\
\text { area } \\
\left(\mathrm{m}^{2} / \mathrm{g}\right)\end{array}$ \\
\hline $\begin{array}{c}\text { Natural } \\
\text { zeolite }\end{array}$ & 8.93 & 0.01 & 19.21 \\
$\mathrm{H}-\mathrm{Za}$ & 7.88 & 0.03 & 65.46 \\
$\mathrm{Fe}^{3+}-\mathrm{Za}$ & 58.74 & 0.11 & 35.97 \\
$\mathrm{Zn}^{2+} \mathrm{Za}$ & 42.60 & 0.10 & 46.41 \\
\hline
\end{tabular}


high activity and stereoselectivity and may reduce any impact on the environment (environmentally friendly). Some parameters which indicate the activity and stereoselectivity of catalyst are the conversion of citronellal, IPA-NIPA quantity produced, and stereoselectivity shown by formation of IPA. Relative activities of catalysts are shown by its conversion (mol\%). The mol of species in the reaction system was determined from the percentage of peak area in total ion chromatogram divided by the molecular weight of the corresponding species. The conversion of citronellal was calculated as:

$C(\operatorname{mol} \%)=\left(X_{o}-X_{t}\right) / X_{o}^{*} 100$

where $C=$ Conversion of citronellal, IPA, or NIPA; $X_{o}=$ mole of citronellal at initial time; $X_{t}$ $=$ mole of citronellal, IPA, or NIPA at $t$ time, while the production of IPA, NIPA, and isopulegol was estimated as follows:

$S(\mathrm{~mol} \%)=X_{I P A} /\left(X_{I P A}+X_{N I P A}\right) * 100$

where $S=$ Stereoselectifity of IPA; $X_{I P A}=$ mole

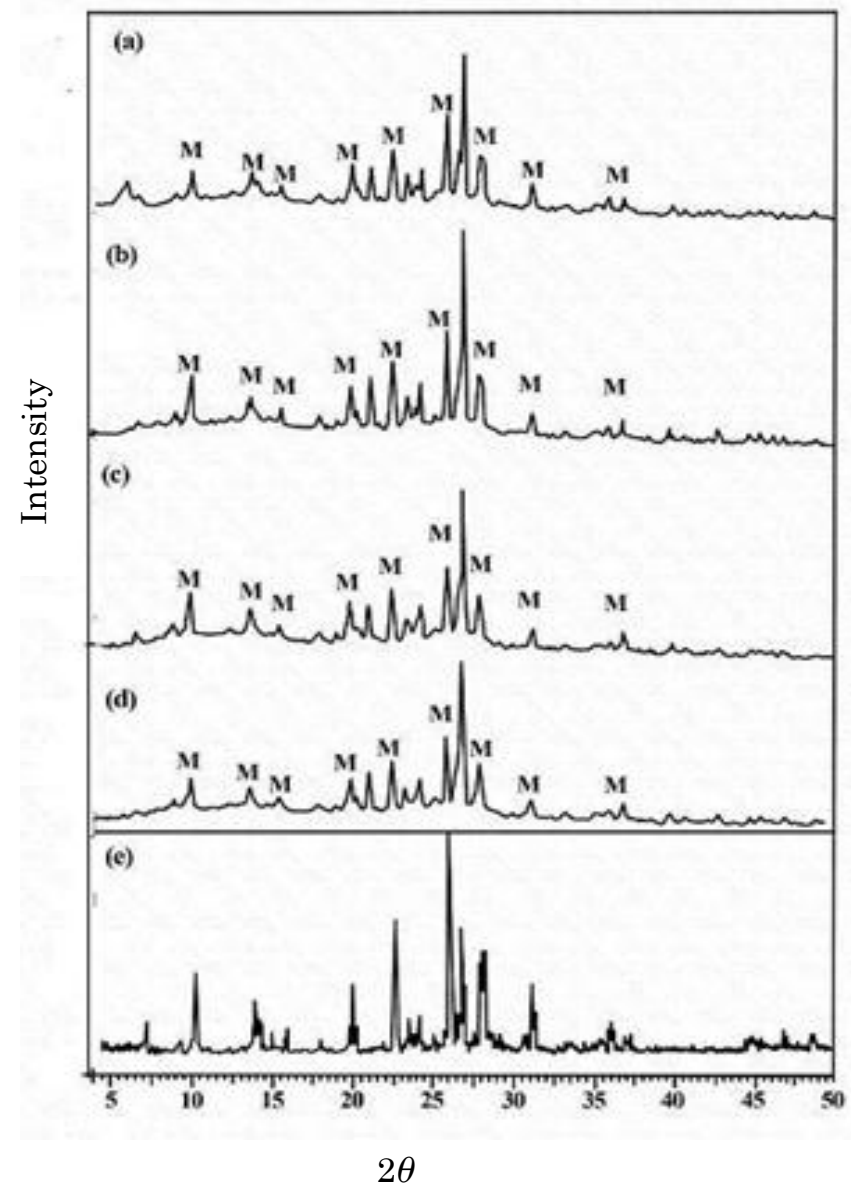

Figure 2. Diffractogram of (a) natural zeolite, (b) $\mathrm{H}-\mathrm{Za}$, (c) $\mathrm{Fe}^{3+}-\mathrm{Za}$, (d) $\mathrm{Zn}^{2+}-\mathrm{Za}$, and (e) synthetic mordenite of IPA; and $X_{\text {NIPA }}=$ mole of NIPA. Table 3 shows a summary of conversion citronellal to IPA-NIPA, and the stereoselectivity of modified natural zeolite catalysts.

Based on the high conversion to IPA and NIPA produced as shown in Table 3, it is known that $\mathrm{Fe}^{3+}-\mathrm{Za}$ catalyst is the most effective catalyst for the cyclisation-acetylation
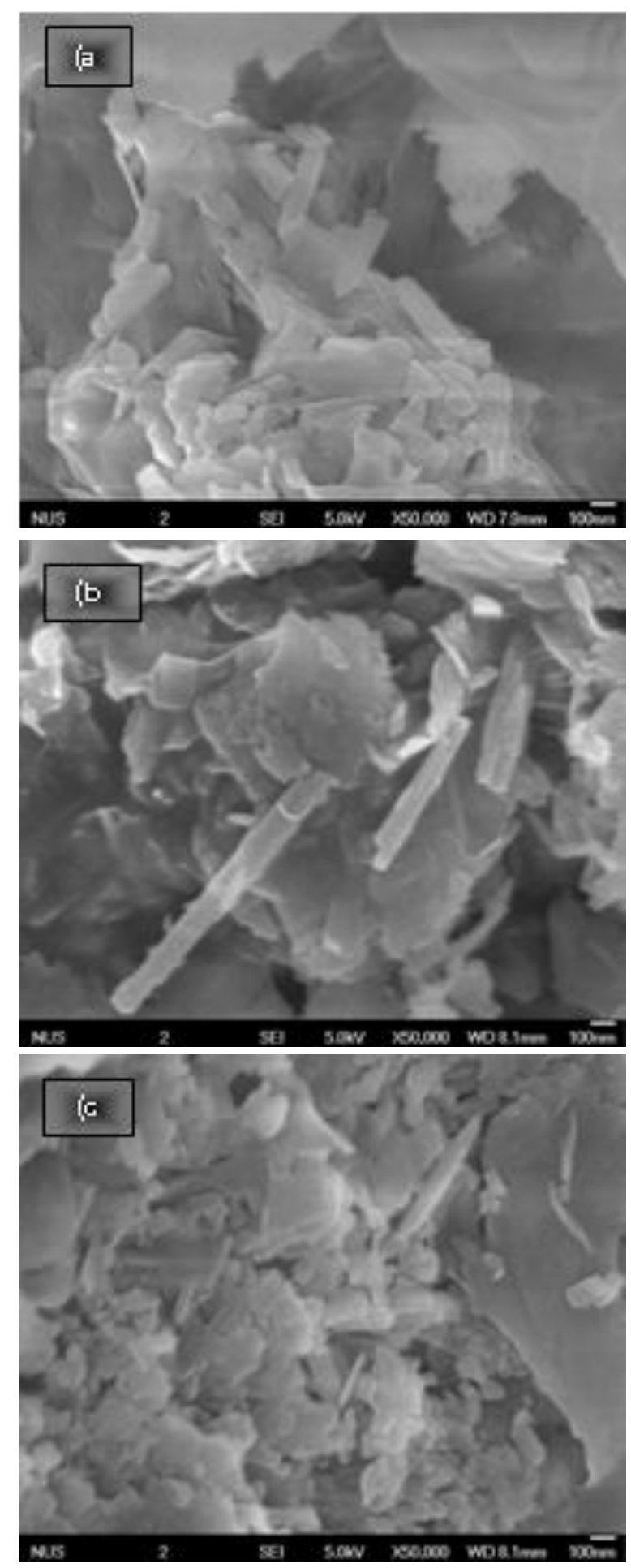

Figure 3. SEM micrograph of H-Za (a), $\mathrm{Fe}^{3+}-\mathrm{Za}(\mathrm{b})$, and $\mathrm{Zn}^{2+}-\mathrm{Za}$ (c) 
of citronellal. Reaction temperature is crucial in catalyst activity. At $0{ }^{\circ} \mathrm{C}$, the activity of the three catalysts was very low. The increase in temperature to $80{ }^{\circ} \mathrm{C}$ increased the activity of catalysts. In general, cyclisation-acetylation of citronellal can be run at $80{ }^{\circ} \mathrm{C}$. $\mathrm{Fe}^{3+}$-Za showed a better activity than $\mathrm{Zn}^{2+} \mathrm{Z} \mathrm{Za}$ and $\mathrm{H}-\mathrm{Za}$ did. Lewis acid plays a role in cetyl cation formation from acetic anhydride. The third factor is the catalyst porosity. Distribution of precursor on the catalyst surface directs the reaction which occurs. If $\mathrm{Fe}^{3+}$ and $\mathrm{Zn}^{2+}$ are more distributed in the porous carrier, the catalyst will have a high stereoselectivity since only the volume of products with specific molecules that can be formed. In contrast, the results of catalyst characterization indicates that $\mathrm{Fe}^{3+}$ and $\mathrm{Zn}^{2+}$ were distributed in the pores and on the outer surface of solids. Closing of small pores by $\mathrm{FeCl}_{3}$ and $\mathrm{ZnCl}_{2}$ hydrate causes the greater average pore radii. In the larger space, dimerization cause decreasing the stereoselectivity of catalyst. H-Za had a smaller average pore radii and a better stereoselectivity, but its high Brönsted acidity caused the formation of isopulegol isomers.

Progressive decrease of citronellal and progressive increase of IPA and NIPA were shown until $180 \mathrm{~min}$ on cyclisation-acetylation reaction with $\mathrm{H}-\mathrm{Za}, \mathrm{Zn}^{2+}-\mathrm{Za}$, and $\mathrm{Fe}^{3+}-\mathrm{Za}$ catalysts as presented in Figure 5. Based on the conversion and the percentage of the product, it can be concluded that the efficient time to produce IPA was $120 \mathrm{~min}$. Lewis acid plays a role of catalyst activity, with acetic anhydride catalyst produces acetyl-like ion in the first step on Friedel-Crafts acylation. According to Freese et al. [21] and Smith et al. [22], an acyl cation produced by reaction of the acetylating agent with the $\mathrm{Zn}^{2+}-\mathrm{Za}$ was proposed to be the critical species reacting with the adsorbed citronellal as a substrate,

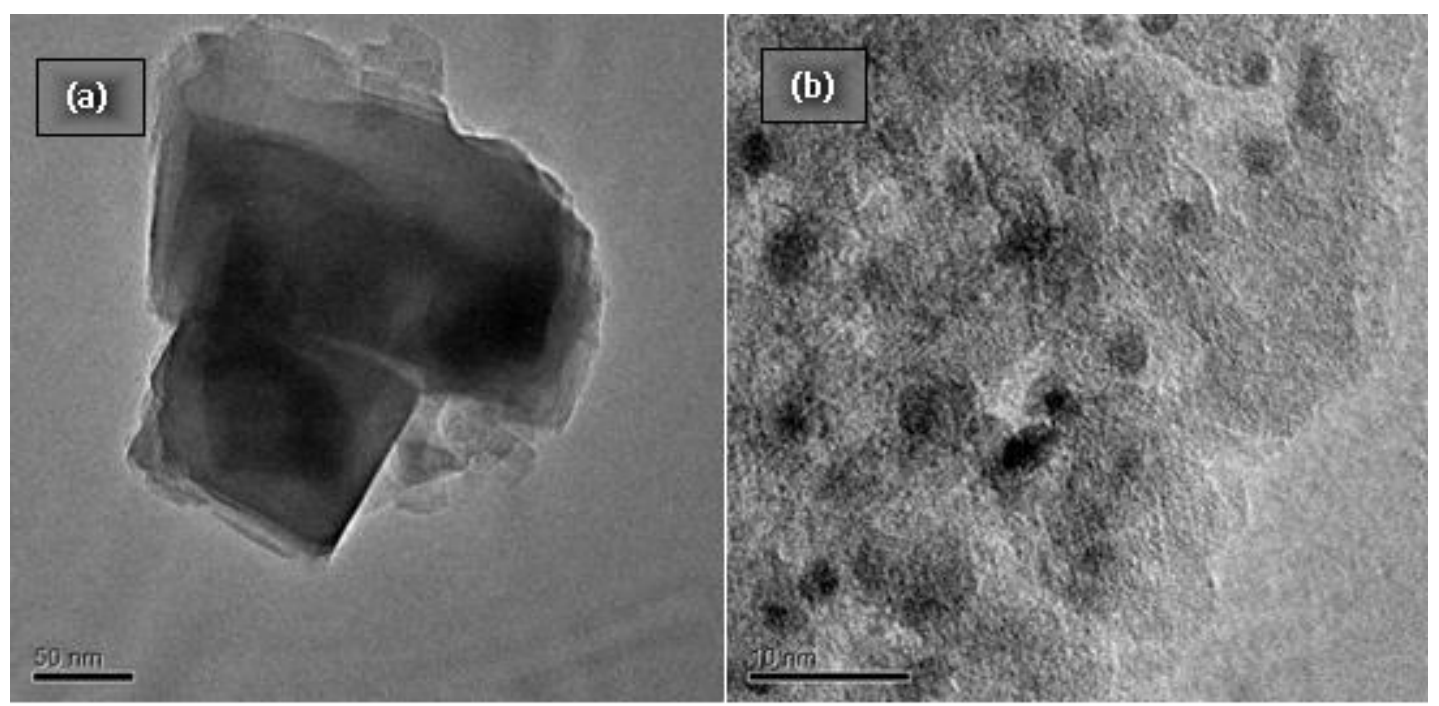

Figure 4. TEM micrograph of $\mathrm{Zn}^{2+}$-Za crystal

Table 3. The citronellal conversion to IPA-NIPA and stereoselectivity of modified natural zeolite catalysts at reaction temperature of 0,30 , and $80^{\circ} \mathrm{C}$.

\begin{tabular}{lcccc}
\hline Catalyst & $\begin{array}{c}\text { Temperature } \\
\left({ }^{\circ} \mathrm{C}\right)\end{array}$ & Time (minute) & $\begin{array}{c}\text { Conversion to } \\
\text { IPA-NIPA (\%) }\end{array}$ & Stereoselectivity of IPA (\%) \\
\cline { 2 - 5 } & 0 & 180 & 0.00 & - \\
$\mathrm{H}-\mathrm{Za}$ & 30 & 180 & 0.00 & - \\
& 80 & 180 & 47.77 & 66.87 \\
\cline { 2 - 5 } $\mathrm{Zn}^{2+}$-Za & 0 & 180 & 0.00 & - \\
& 30 & 180 & 0.00 & - \\
\hline \multirow{3}{*}{$\mathrm{Fe}^{3+}$-Za } & 0 & 180 & 56.82 & 75.67 \\
& 30 & 180 & 1.92 & 76.73 \\
\hline
\end{tabular}



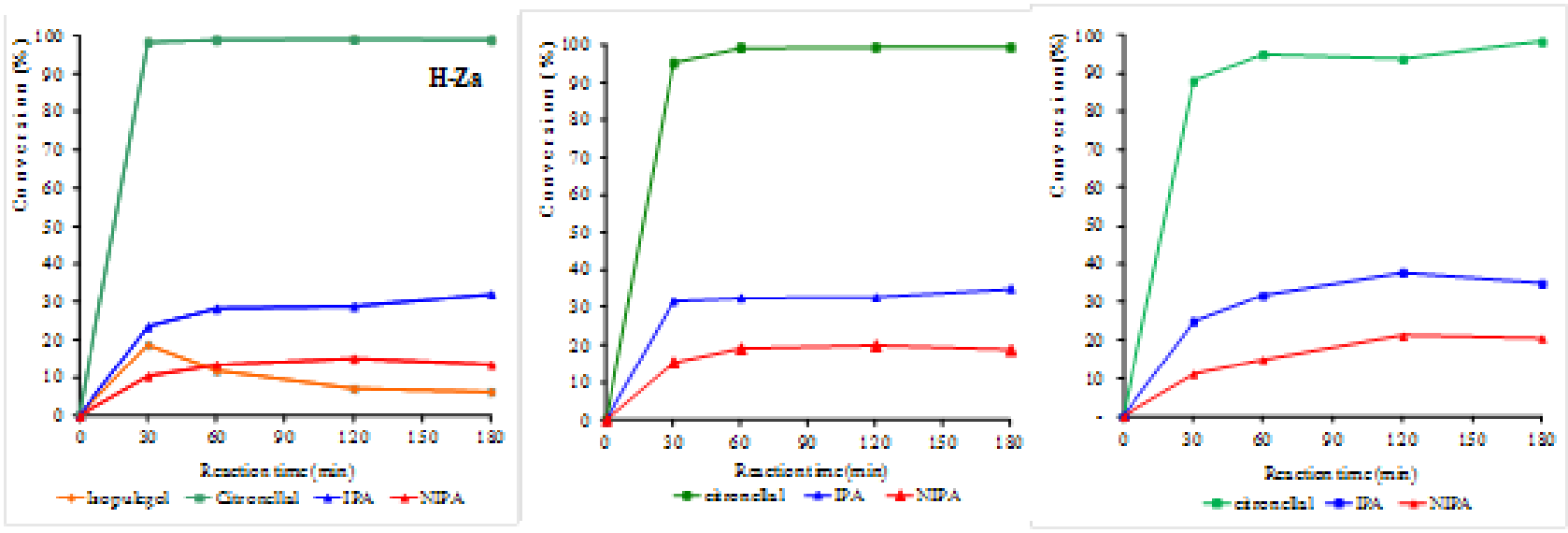

Figure 5. Catalysis of $\mathrm{H}-\mathrm{Za}, \mathrm{Zn}^{2+}-\mathrm{Za}$, and $\mathrm{Fe}^{3+}-\mathrm{Za}$ on the cyclisation-acetylation of citronellal at 80 ${ }^{\circ} \mathrm{C}$ as a function of reaction time.

implying that reaction of the acyl cation- $\mathrm{Zn}^{2+}$. $\mathrm{Za}$ complex with the citronellal as a substrate was the rate-determining step [23].

The reusability of solid catalysts is one of their main advantages over liquid homogeneous catalysts [24]. This characteristic for the $\mathrm{Zn}^{2+} \mathrm{Za}$ catalyst in the cyclisationacetylation reactions of citronellal with acetic anhydride was evaluated by running consecutive reaction cycles using the same reaction conditions as described earlier. Each reaction cycle took $180 \mathrm{~min}$. After the first reaction cycle, reaction mixtures were decanted, the catalyst was recovered than rinsed with $n$-hexane, and a new reaction cycle was started with fresh reactants. The initial catalytic activity of $\mathrm{Zn}^{2+}-\mathrm{Za}$ is plotted in Figure 5 . Deactivation of catalyst in the second cycle is shown in Figure 6.

Catalytic activity of $\mathrm{Zn}^{2+}$ - Za after $180 \mathrm{~min}$ in second cycle is lower than that in first cycle. Deactivation of catalyst is shown by concentration (\% GC) of citronellal after 180 min, but selectivity of recovered catalyst was higher than selectivity of fresh catalyst. The decrease in activity of catalysts might be caused by the decrease in the concentration of the active cations $\left(\mathrm{Fe}^{3+}\right.$ and $\left.\mathrm{Zn}^{2+}\right)$ due to the treatment in the first-cycle experiment causing the decrease in the formation of side products and the increase in the selectivity of catalyst. This phenomenon was supported by the data in Table 2. The activity of $\mathrm{Fe}^{3+}-\mathrm{Za}$ was higher compared to that of $\mathrm{H}-\mathrm{Za}$ and $\mathrm{Zn}^{2+}-\mathrm{Za}$. However, its stereoselectivity was lower. By using the same catalysts at different temperatures, the activity of all catalysts increased with increasing temperatures but the selectivity of $\mathrm{Fe}^{3+}$-Za catalyst decreased with increasing temperatures.



Figure 6. Catalysis of regenerated $\mathrm{Zn}^{2+}-\mathrm{Za}$ on the cyclisation-acetylation of citronellal at $80{ }^{\circ} \mathrm{C}$ as a function of reaction time.

\section{Conclusions}

The mineralogical composition of natural zeolite used in this experiment was dominated by mordenite. The main product of cyclisationacetylation of $(R)-(+)$-citronellal was IPA (isopulegyl acetate) and NIPA (neo-isopulegyl acetate). The highest yield of IPA and NIPA was obtained by $\mathrm{Fe}^{3+}-\mathrm{Za}$ catalyst $(78.69 \%)$ at 80 ${ }^{\circ} \mathrm{C}$ and $120 \mathrm{~min}$. Lewis acidity plays the role in the formation of acetyl ionic from acetic anhydride. The activity and stereoselectivity of catalysts depended on Lewis acidity and cation distribution on the catalyst surface.

\section{Acknowledgments}

The authors would like to thank Prof. Chuah Gaik Khuan (National University of Singapore) for the opportunity to use the instruments for catalyst characterisation. 


\section{References}

[1] Nhu-Trang, T.T, Casabianca, H., GreinerLoustalot, M.F. (2006). Authenticity Control of Essential Oils Containing Citronellal And Citral by Chiral and Stable-Isotope Gas-Chromatographic Analysis. Anal. Bioanal. Chem., 386: 2141-2152.

[2] Arras, J., Steffan, M., Shayeghi, Y. and Claus, P. (2008). The Promoting Effect of a Dicyanamide Based Ionic Liquid in The Selective Hydrogenation of Citral. Chem. Commun., 34: 4058-4060.

[3] Alvaro, M., Corma, A, Das, D., Fornés, F., García, H. (2005). "Nafion"-Functionalized Mesoporous MCM-41 Silica Shows High Activity and Selectivity For Carboxylic Acid Esterification and Friedel-Crafts Acylation Reactions. J. Catal., 23: 48-55.

[4] Sheldon, R.A. (1997). Catalysis and Pollution Prevention . Chem Ind (London) 12-15.

[5] Sheldon, R.A., Bekkum, H.V. (2000), Fine Chemicals through Heterogeneous Catalysis, Wiley VCH, Weinheim.

[6] Gadekar, L. S., Katkar, S. S., Vidhate, K. N., Arbad, B. R., Lande, M.K. (2008). Modification, Characterization and Catalytic Potency of Modified Natural Zeolite for Knoevenagel Condensation Reaction. Bull. Catal. Soc. India. 7: 76-83.

[7] Hartati, H., Santoso, M., Triwahyono, S., Prasetyoko, D. (2013). Activities of Heterogeneous Acid-Base Catalysts for Fragrances Synthesis: A Review. Bull. Chem. React. Eng. Catal. 8(1): 14-33.

[8] Chuah, G.K., Liu, S.H., Jaenicke, S., Harrison, L.J. (2001). Cyclization Citronellal to Isopulegol Catalyzed by Hydrous Zirconia and Other Solid Acids. J. Catal. 200: 352-359

[9] Yongshong, Z., Yuntong, N., Jaenicke, S., Chuah, G.K. (2004). Cyclisation of Citronellal over Zirconium Zeolite beta - a Highly Diastereoselective Catalyst to $( \pm)$-Isopulegol. J. Catal. 229: 404-413.

[10] Cahyono, E., Pranowo, H.D., Muchalal, M., Triyono, T. (2010). Redox reaction in The Cylation Cyclisation-Aromatisation of $(R)-(+)$ Citronellal with $\mathrm{FeCl}_{3}$ /Acetic anhydride. Eksakta Jurnal Ilmu-ilmu MIPA, 2: 79-85

[11] Delannay, F. (1984). Characterization of heterogeneous catalysis; Marcel Dekker: New York.

[12] Maria, C., Abello, M.C., Velasco, V.P., Gomez, M.F., Rivarola, J.B. (1997). Temperature-Programmed Desorption of $\mathrm{NH}_{3}$ on $\mathrm{Na}-\mathrm{Y}$ Zeolite. Langmuir. 13: 2596-2599
[13] Cahyono, E. (2012). Acidity Measurement of Modified Natural Zeolite with $\mathrm{NH}_{3}$-TPD Method, Proceedings, National Seminar on Chemistry and Chemistry Education, UnsoedUnnes-Undip-UNS-HKI.

[14] Cahyono, E., Pranowo, H.D., Muchalal, M., Triyono, T. (2013). Analysis Of The Enantiomers Ratio of Citronellal From Indonesian Citronella Oil Using Enantioselective Gas Chromatography. Malaysian Journal of Fundamental and Applied Sciences. 9(2): 62-66.

[15] Ostroski, I.C., Barros, M.A.S.D., Silva, E.A., Dantas, J.H., Arroyo, P.A., Lima, O.C.M. (2009). A Comparative Study For The Ion Exchange of $\mathrm{Fe}(\mathrm{III})$ and $\mathrm{Zn}(\mathrm{II})$ On Zeolite NaY. J. Haz. Mat. 16: 1404-1412.

[16] Hernáandez, M.A., Corona, L., Rojas, F. (2000). Adsorption Characteristics of Natural Erionite, Clinoptilolite and Mordenite Zeolites from Mexico. Adsorption. 6(1): 33-45

[17] Xi, H., Li, Z., Zhang, H. Li, X., Hu, X. (2003). Estimation of Activation Energy For Desorption of Low-Volatility Dioxins on Zeolites By TPD Technique. Sep. Purif. Technol. 31: 41-45.

[18] Mockovciakova, A., Matik, M., Zuzana Orolınova, Z, Hudec, P., Kmecova, E. (2008). Structural characteristics of modified natural zeolite. J. Porous Mater. 15: 559-564

[19] Guisnet, M., Ayrault, P., Coutanceau, C., Alvarez, M.F., Datka, J. (1997). Acid Properties of Dealuminated Beta Zeolites Studied by Irspectroscopy. J. Chem. Soc. Faraday Trans. 93: 1661-1665.

[20] Sharma, P., Rajaram, P., Thomar, R. (2008). Synthesis And Morphological Studies of Nanocrystalline MOR Type Zeolite Material. J. Colloid Interf. Sci. 325: 547-557.

[21] Freese, U., Heinrich F., Roessner, F. (1999). Acylation of Aromatic Compounds on H-Beta zeolites, Catal. Today. 49(1-3): 237-244.

[22] Smith, K., Zenhua, Z., Hodgson, P.K.G. (1998). Synthesis of Aromatic Ketones by Acylation of Aryl Ethers with Carboxylic Anhydrides in the Presence of Zeolite H- $B$ (H-BEA) in the Absence of Solvent. J. Mol. Cat. AChem. 134: 121-128.

[23] Cahyono, E., Muchalal, M., Triyono, T., Pranowo, H.D. (2010). Cyclisation-Acetylation Kinetic Of $(R)-(+)$-Citronellal By $\mathrm{Zn}^{2+}-$ Natural Zeolite as Solid Solvent Catalyst, Indo. J. Chem. 10(2): 189-194.

[24] Liu, Y., Lotero, E., Goodwin Jr., J.G. (2006). Effect of Carbon Chain Length on Esterification of Carboxylic Acids with Methanol Using Acid Catalysis. J. Catal. 243: 221-228. 